\title{
PERANCANGAN BUKU DONGENG TELAGA WARNA
}

\author{
Purmaningrum Maeni ${ }^{1}$, Hedi Hadiansyah ${ }^{2}$, Annisa Insyirah ${ }^{3}$ \\ 1,2,3 Desain Komunikasi Visual-, Universitas Pasundan
}

\begin{abstract}
Abstrak:
Keluarga merupakan tempat pertama anak untuk mengedukasi diri salah satunya mengenai nilai positif kehidupan, Menanamkan nilai-nilai positif kehidupan kepada anak tidaklah mudah namun dapat dilakukan dari usia prasekolah, salah satu alternatif untuk membantu orang tua dalam menanamkan nilai positif kepada anak adalah melalui dongeng, karena dengan dongeng akan mempermudah untuk menyampaikan pesan positif yang terkandung dalam cerita tersebut. Salah satu cara untuk memudahkan penyampaiannya dapat dibantu dengan menggunakan gambar ilustrasi dalam berbagai media. Ilustrasi semi realis lebih mudah dipahami oleh anak2 sebagai target audiance untuk membantu menyampaikan pesan moral. Media alternative berupa buku dongeng Interaktif dianggap sebagai media yang ramah bagi anak dan praktis dan dengan tambahan interaksi sederhana akan menambah interaksi yang terjadi antara orang tua dan anak. Tema yang diangkat dalam perancangan ini adalah mengenai dongeng telaga warna, karena banyak orang tua yang tidak tahu mengenai dongeng telaga warna serta pesan positif dalam dongeng telaga warna tersebut, meski lebih banyak yang tahu bahwa telaga warna merupakan tempat wisata.
\end{abstract}

Kata Kunci : Ilustrasi, Dongeng, Buku, Telaga Warna.

\begin{abstract}
Family is the first place for children to educate themselves one of them about the positive value of life, Instilling positive values of life for children is not easy but can be done from preschool age, one alternative to help parents to instill positive value to children is through fables, because with fairy tales it will be easier to convey the positive message contained in the story. One way to facilitate the delivery can be helped by using illustrations in various media. Semi-realist illustrations are easier for children to understand as audian targets to help convey moral messages. Alternative media in the form of Interactive fairy tales are considered as media that are child-friendly and practical and with the addition of simple interactions will add to the interactions that occur between parents and children. The theme raised in this design is about fairy tales of color, because many parents did not know about Talaga Warna tale and positive messages in Talaga Warna, although more people know that Talaga Warna is a tourist spot.
\end{abstract}

Keywords: Illustrations, Tales, Books, Telaga Warna.

\section{PENDAHULUAN}

Keluarga merupakan tempat pertama anak untuk mengedukasi diri, baik secara akademis maupun secara moral. Keakraban dalam keluarga merupakan hal yang sangat penting, semakin akrab orang tua bersama anak semakin besar juga kemungkinan anak untuk meniru orang tuanya. Keakraban disini bukan hanya mengenai kontak fisik seperti pelukan ataupun ciuman kasih sayang, melebihi itu keakraban dapat berupa hubungan interaksi yang terjalin antara orang tua dan anak terutama kepada anak usia prasekolah yang masih berpikiran abstrak dan penuh akan imajinasi. Orang tua berhak akan peran tersebut dan perlu untuk mengenal dunia, imajinasi dan fantasi si anak. Dalam pengembangannya keakraban antara orang tua dan anak dapat dilakukan dengan meningkatkan intensitas berinteraksi dengan anak, salah satunya melalui dongeng. Dongeng 
sendiri dapat diartikan sebagai menceritakan secara lisan sebuah cerita yang biasanya berupa cerita khayal atau imajinatif yang didalamnya mengandung pesan moral dan nilai-nilai positif yang dapat diterapkan dalam kehidupan seharihari. Nilai positif yang terkandung di dalamnya biasanya berupa petunjuk perbuatan baik dan perbuatan buruk. Dongeng merupakan sarana paling lengkap dalam komunikasi, karena di dalamnya terdapat intonasi, aksen, tekanan kata, keras pelannya suara, gerak tubuh, mimik wajah dan lain-lain. Hal tersebut bertujuan untuk memperjelas pesan yang ingin disampaikan. Kelebihan dongeng selain menciptakan kontak hubungan fisik antara pendongeng dan pendengar dalam hal ini orang tua adalah pendengar dapat memberi reaksi langsung mengenai cerita yang di dongengkan atau bahkan pendongeng dapat mengecek apakah pesan yang disampaikan tersebut dipahami oleh si pendengar. Dengan ditemukannya teknologi cetak dongeng dapat dibukukan hal ini mengakibatkan dongeng dapat dinikmati oleh umum, meskipun begitu komunikasi yang terjadi menjadi satu arah. Dengan begitu peran orang tua dalam mendongeng kepada anak sangatlah penting, terutama pada usia anak yang belum dapat membaca.

Meskipun begitu menurut data yang di dapat minat orang tua dalam mendongeng masih cukup besar. Permasalahan disini adalah orang tua dengan segala kendala dalam mendongeng yang dialaminya masih berminat dalam mendongeng namun fasilitas yang mendukung orang tua dalam mendongeng perlu ditingkatkan.

Anak-anak sendiri paling efektif untuk diceritakan dongeng adalah pada usia pra sekolah karena pada rentan usia ini perkembangan anak sedang mengalami perkembangan yang pesat serta pemikiran yang masih abstrak dan imajinatif sehingga sulit untuk menanamkan nilai-nilai positif kehidupan kepada anak, karena itu dengan mendongeng yang merupakan penyampaian secara lisan sebuah cerita yang biasanya berupa khayal atau imajinatif maka anak akan lebih mudah memahami dan mencerna pesan yang ingin disampaikan. Keseharian yang dilakukan anak usia pra sekolah kebanyakan adalah bermain untuk mengasah keingin tahuan mereka dan memperhatikan hal-hal yang menarik perhatiannya. Anak usia pra sekolah belum dapat membaca sehingga dongeng menjadi amat penting dalam penyampaian pesan yang terkandung di dalam cerita tersebut. Dalam mendongeng orang tua mengaku terbantu akan adanya buku bacaan, terutama untuk buku bergambar karena selain anak menjadi lebih tertarik untuk menyimak orang tua pun menjadi lebih mudah dalam mendongeng selain karena faktor bahwa sebenarnya orang tua merasa cukup khawatir jika anaknya terlalu sering menggunakan gadget. Berkaitan dengan objeknya, dongeng telaga warna sendiri dipilih karena menurut data yang diperoleh banyak orang tua ataupun anak yang tidak mengetahui isi cerita dongeng telaga warna, meski lebih banyak dari mereka yang mengetahui telaga warna merupakan sebuah objek wisata yang indah. Dibalik indahnya talaga warna terdapat sebuah dongeng yang mengndung nilai-nilai positif serta pesan moral yang dapat dikenalkan kepada anak, terutama pada anak usia prasekolah. Oleh karena itu dibutuhkan media mendongeng yang dapat disesuaikan dengan minat dan karakter anak usia prasekolah untuk menanamkan nilainilai positif yang terdapat pada dongeng, dalam hal ini dongeng telaga warna agar dapat ditanamkan dalam kehidupan sehari-hari.

\section{KAJIAN PUSTAKA}

$\begin{array}{cc}\text { Menurut } & \begin{array}{l}\text { Sugihastuti dalam Tentang } \\ \text { Cerita Anak (2013) dongeng adalah }\end{array}\end{array}$ menceritakan secara lisan sebuah cerita yang biasanya bersifat khayal atau imajinatif dalam perkembangannya sendiri dapat berupa cerita yang benar-benar terjadi misalkan mengenai tumbuhan ataupun hewan dengan dipersonifikasi ke kehidupan manusia. Bahan dongeng sendiri dapat diperoleh melalui tulisan seperti buku. Saat proses mendongeng terjadi emosi anak dalam keadaan tergerak hal ini dikarenakan terpengaruh oleh tema dan masalah dongeng yang diceritakan. misalkan ketika pendongeng mengisahkan sesuatu yang menyenangkan anak akan ikut merasa senang begitupun jika cerita yang didongengkan sedih anak pun akan ikut merasa sedih. Perasaan anak sebagai pendengar biasanya dibangkitkan oleh segala sesuatu hal dalam dongeng tersebut, misalnya sifat dan prilaku tokoh yang dapat memperkuat dan mempertajam imajinasinya. disinilah letak peran pendongeng untuk dapat menyampaikan pesan-pesan yang terkandung 
dalam dongeng. Unsur mendidik biasanya menjadi pesan utama yang ingin disampaikan.

Menurut Murti Bunanta, pendiri Kelompok Pecinta Bacaan Anak (KPBA) dalam artikel di suara.com (2016) menuturkan bahwa ada dua cara mendongeng yang bisa dilakukan orangtua, yaitu mendongeng dengan membacakan buku, serta mengolah dan mengembangkan cerita dari buku menjadi cerita sendiri. Jika mendongeng yang sumbernya dari buku, semua cerita cocok untuk anak usia berapapun hanya saja orang tua harus dapat memilah cerita anak yang cocok untuk anak diusinya. Sedangkan untuk cara kedua, di mana orangtua mengolah dan mengembangkan cerita dari buku, menjadi cerita sendiri. Ada hal yang harus diperhatikan yaitu pemilihan kata karena tidak semua kata dapat dimengerti oleh anak. Selain itu, pula pemakaian kata yang bersifat negatif seperti kata-kata mengumpat yang kasar. Dari penuturannya dapat disimpulkan terdapat dua cara dalam mendongeng yaitu dengan menggunakan buku dan mendongeng secara langsung dengan mengembangkan cerita dari buku menjadi cerita sendiri. Tetapi apapun pilihan cara mendongengnya. Meskipun tidak secara langsung dapat disimpulkan tetapi diketahui buku dapat mempermudah orang tua dalam mendongeng dengan memberikan patokan/panduan ataupun referensi bagi orang tua untuk mendongeng.

Menurut Kak Bimo salah seorang pendongeng nasional dalam bukunya yang berjudul Mahir mendongeng (2011) mengungkapkan jika bercerita atau mendongeng dapat menjadi alternatif media dalam menyampaikan pembelajaran baik pelajaran berupa agama, pendidikan imajinatif, pendidikan emosional, Membantu proses identifikasi diri melalui perbuatan dan lain sebagainya. Disinilah kesempatan bagi orang tua untuk dapat menanamkan pembelajaran mengenai kehidupan dengan lebih mudah karena penyampaian dongeng yang menarik mampu membuat anak lebih memperhatikan dan lambat laun mulai terpengaruh oleh dongeng itu sendiri.

Bruno Bettlheim, guru besar Emeritus pada jurusan Psikologi dan Psikiatri Universitas Chicago, America Serikat, berpendapat bahwa cerita yang menarik untuk anak haruslah merangsang imajinasi, membantu mengembangkan kecerdasan, menjernihkan emosi, dan menyesuaikan diri dengan kecemasan

ketika ia dihadapkan pada pencarian jalan keluar. Cerita untuk anak selayaknya berkaitan dengan anak. Misalnya saja, dongeng-dongeng yang merefleksikan pandangan anak tentang dunia. (Artikel Children need fairy tales, Bruno Bettlheim) Buku cerita merupakan salah satu media yang paling disukai oleh anak-anak terutama yang memiliki ilustrasi dan sedikit permainan (buku interaktif) yang melibatkan anak, maka anak akan merasa berada dalam cerita. interaktif yaitu:

\section{Dapat Disentuh}

Buku adalah salah satu benda yang memberikan informasi dalam bentuk nyata yang dapat disentuh serta dalam lingkungan buku sendiri dapat berupa hiasan yang menghias suatu ruangan.

2. Sumber Referensi Terpercaya

Memang tidak semua Referensi dalam buku dapat dipercaya, akan tetapi dalam membuat kajian pustaka, buku memegang salah satu peranan penting dalam memberikan tambahan bahan dalam penulisannya.

3. Hemat

Dalam memiliki buku seseorang juga dapat berhemat karena dalam menggunakan buku seseorang tidak perlu membayar listrik untuk mencari sebuah informasi.

\section{Adanya Interaksi}

Dalam buku, khususnya buku Interaktif terdapat interaksi-interaksi sederhana yang melibatkan si pembaca sehingga dapat menambah keseruan dan daya imajinasi anak.

Media pembelajaran merupakan kegiatan yang bertujuan untuk menyalurkan pesan dalam hal ini bahan pembelajaran penanaman moral sehinggga dapat merangsang perhatian,minat hingga perasaan dan dalam pembelajaran mengenai nilai-nilai positif kehidupan untuk anak buku cerita yang didongengkan dapat

menjadi salah satu alternatif media pembelajarannya. Anak usia prasekolah dapat 
dikatakan sebagai masa bermain karena waktunya diisi dengan bermain. Yang dimaksud dengan bermain disini adalah kebebasan batin untuk memperoleh kesenangan. Terdapat berbagai permainan anak dan salah satunya adalah permainan Reseptif atau apresiatif seperti mendengar cerita ataupun dongeng. (Abu ahmadi dalam Psikologi perkembangan anak dan Remaja, 2016). Permainan seperti mendengar dongeng ini mampu menstimulus anak untuk mengenal berbagai macam watak, peristiwa, sikap dan emosional yang mampu untuk meningkatkan aspek perkembangan kejiwaan anak.

\section{METODE PENELITIAN}

Dalam penelitian dan perancangan ini diperlukan data sebagai bahan untuk kebutuhan analisis serta perancangan media yang tepat sasaran dan sesuai dengan minat serta karakter anak usia prasekolah. Data tersebut dapat diperoleh melalui studi literature, wawancara, kuesioner dan hasil observasi di lapangan demi untuk mengetahui pemahaman mengenai kondisi di lingkungan, pemahaman mengenai dongeng khususnya dongeng telaga warna, Ketertarikan dalam mendongeng serta pembanding media yang nantinya akan menentukan keputusan media dan konten yang baik disampaikan dalam perancangan ini.

Wawancara pertama dilakukan kepada target yang berusia 3,5 tahun sampai dengan 6 tahun, wawancara ini dilakukan untuk mengetahui bagaimana pemahaman, ketertarikan dan apakah mendongeng masih dilakukan serta kegiatan yang biasanya dilakukan sehari-hari. Dari wawancara kepada target didapatkan bahwa anak usia pra sekolah biasanya menghabiskan waktunya dengan bermain dan belajar mengenai hal-hal yang menarik perhatiannya, sample target yang diwawancarai ini secara tidak langsung tahu mengenai dongeng karena pernah didengarkan cerita dari orang tuanya. Sample Target umumnya belum dapat membaca meski sudah dibelikan buku tetapi target lebih suka melihat gambar-gambarnya, target yang diwawancarai belum bersekolah dan hanya belajar di rumah. Dari hasil wawancara dengan target disimpulkan bahwa pada usia anak pra sekolah biasanya dihabiskan dengan bermain yang merupakan salah satu cara untuk meningkatkan pengetahuan mereka mengenai hal-hal disekitarnya, Karena belum bersekolah/ masih TK maka anak usia ini umumnya belum dapat membaca sehingga dongeng sangatlah penting untuk menanamkan nilai positif kehidupan kepada mereka.

Wawancara kedua dilakukan kepada orang tua target, hal ini didasari untuk mengetahui pemahaman mengenai dongeng dan telaga warna dari sudut pandang orang tua semua itu dikarenakan mendongeng adalah salah satu peran orang tua dalam keluarga, serta mengetahui pemikiran mengenai dongeng dan apakah kegiatan mendongeng masih dilakukan. Dari wawancara kedua ini didapatkan bahwa orang tua mengaku terkadang masih mendongeng kepada anak, hal yang membuat orang tua sulit mendongeng salah satunya adalah waktu dan tenaga namun minat orang tua dalam masih sangatlah besar.

Untuk dongeng telaga warna khususnya sample kurang mengetahui isi dari dongeng telaga warna hal ini disebabkan karna sample hanya pernah mendengarnya ataupun memang tidak tahu sama sekali.sample adalah orang tua yang keduanya bekerja dan orang tua yang hanya salah satu yang bekerja, dari kedua sample tersebut didapatkan orang tua yang keduanya bekerja lebih sedikit mendapatkan waktu bersama anaknya dari pada orang tua yang hanya satu pihak yang bekerja namun minat keduanya dalam mendongeng masih sangat besar.

Dari hasil wawancara kepada target yaitu anak usia 3,5 - 6 tahun dan orangtua. Dapat disimpulkan jika keseharian anak lebih banyak dihabiskan dengan bermain, anak usia pra sekolah umumnya belum dapat membaca sehingga peran orang tua dalam mendongeng sangatlah penting. Meskipun orang tua disibukkan oleh urusannya namun minat orang tua dalam mendongeng masih sangatlah besar.

Kuesioner ini dilakukan untuk mengetahui pemahaman mengenai dongeng dan telaga warna sebagai cerita yang akan disampaikan serta media yang diharapkan. Kuesioner dibagikan kepada 42 responden di daerah Dago dan Sadang serang, Bandung. Yang dijadikan responden untuk mengisi kuesioner ini adalah orang tua yang memiliki anak usia 3,5 tahun sampai 6 tahun. Berikut hasil kuesioner tersebut: 


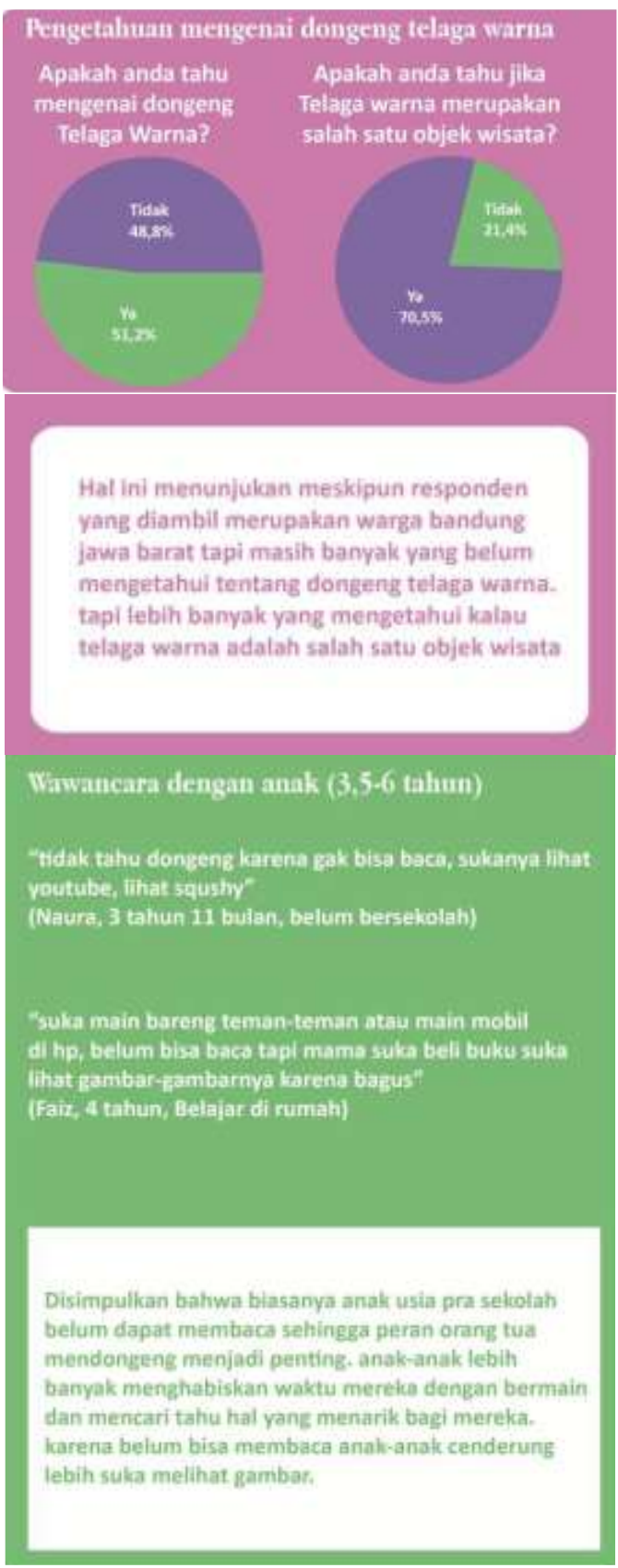

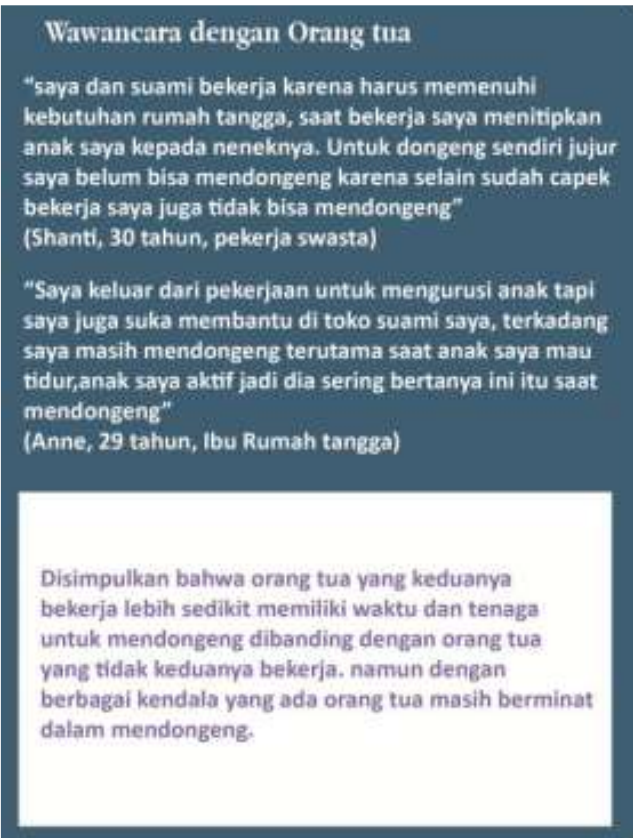

\section{Kesimpulan}

Dari beberapa data kuesioner dan wawancara yang didapat disimpulkan bahwa dongeng telaga warna dirasa tidak begitu populer namun lebih banyak yang tahu jika telaga warna adalah objek wisata. daln dalam mendongeng kepada anak orang tua lebih banyak yang memilih buku daripada media yang berbau teknologi hal itu tak lepas karena sebenarnya orang tua cukup khawatir jika anaknya terlalu sering bermain gadget. meskipun banyak kendala dalam mendongeng tapi anak usia pra sekolah umumnya belum dapat membaca dan lebih banyak menghabiskan waktu dengan bermain maka peran orang tua menjadi penting disini.

Sumber data Pribadi (2018)

Pado beberopa sample Orang twa yang memiliki anak usia $3,5-6$ tohum dan Anak usia 3,5-6 tahum

\section{Hasil Kuesioner dan Wawancara 1}

Sumber Penelitian Pribadi (2018)

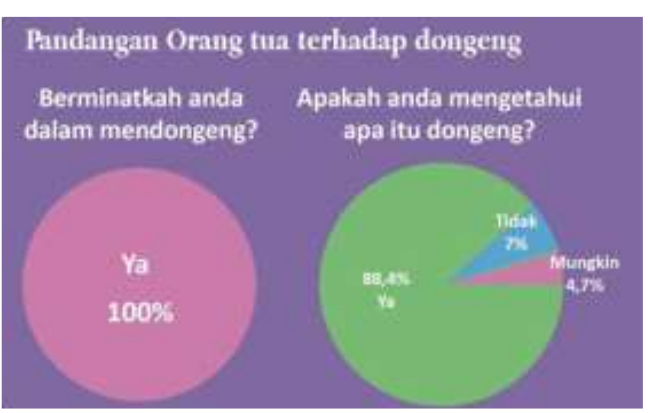


hal ini menunjukan jika orang tua masih memiliki minat yang tinggi dalam mendongeng dan banyak orang tua tahu setidaknya apa itu dongeng sehingga dongeng bukanlah hal yang asing di telinga mereka.

Masihkalı kegiatiu Mendongeng dilaksanakan Apakah anda masih

mendongeng kepads anak?

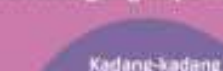

$41,9 \times$

notat

$27,9 x$

$302 x$

hal ini menunjukan jika presentase orang tua yang masih ,jarang dan tidak untuk mendongeng masth cukup merata. namun jika digabungkan yang masih dan jarang mendongeng jauh melebihi yang tidak mendongeng sehingga dapat disimpulkan orang tua sebisa mungkin inf̧in mendongeng hepada anakinya.

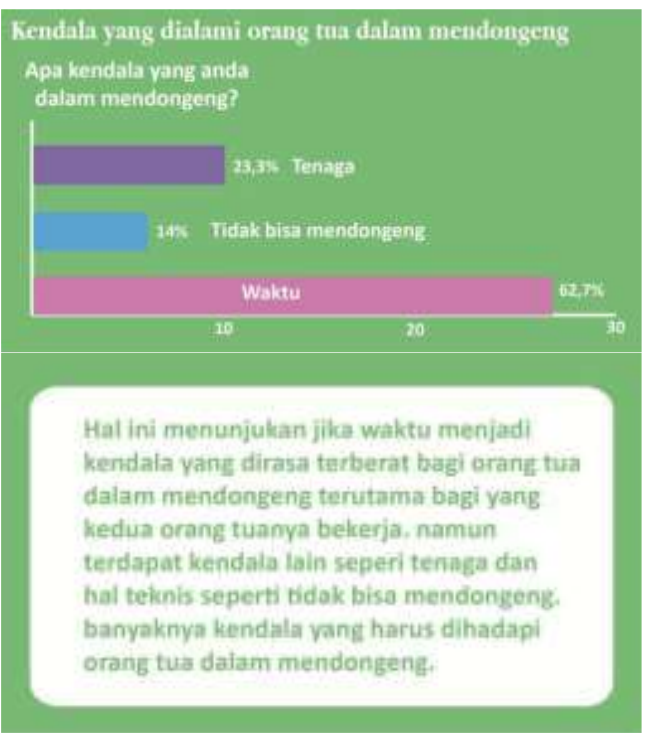

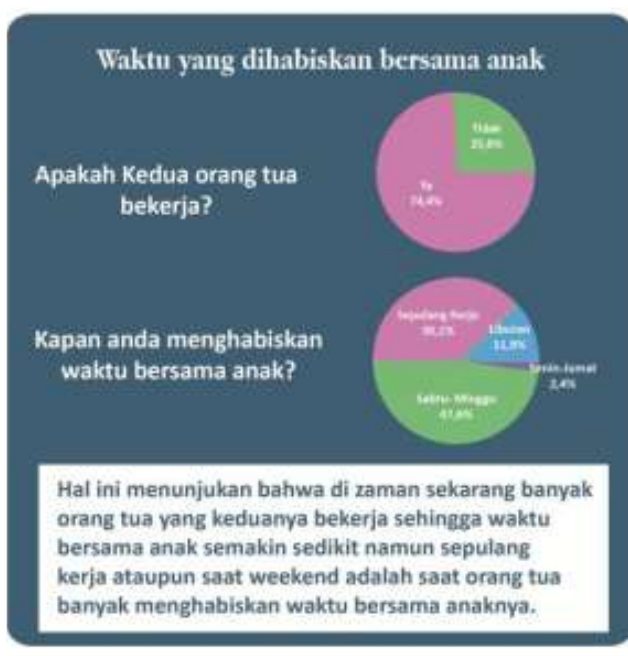

\section{Kesimpulan}

Dari beberapa data kuesioner, dapat disimpulkan bahwa orang tua masih memiliki minat yang tinggi dalam mendongeng dan mendongeng sendiri bukanlah hal yang asing bagi orang tua. dengan semua kendala yang dihadapi,orang tua masih menyempatkan diri untuk mendongeng meskipun tidak terlalu sering. hal ini menunjukan kesadaran orang tua akan pentingnya mendongeng masih cukup tinggi. meski di zaman sekarang sudah banyak orang tua yang keduanya bekerja sehingga lebih sedikit memiliki waktu bersama anak.

Sumber dato Pribodi (2018)

Pada beberopa sample Orang tua yang memillki anak usia 3,5-6 tahun

\section{Hasil Kuesioner dan Wawancara 2}

Sumber Penelitian Pribadi (2018)

Disimpulkan bahwa orang tua dengan segala kendala yang mereka hadapi masih memiliki minat yang tinggi dalam mendongeng hal ini juga terlihat dari jawaban orang tua yang meskipun mengeluh karena waktu dan tenaga yang terkuras apalagi di jaman sekarang banyak orang tua yang keduanya bekerja tetapi masih menyempatkan diri untuk mendongeng meskipun intensitasnya tidaklah sering. Untuk telaga warna khususnya banyak orang tua yang tidak tahu tentang dongeng telaga warna,tapi lebih banyak yang mengetahui telaga warna adalah tempat wisata. Dalam mendongeng media yang dipilih orang tua cenderung adalah buku hal ini dikarenakan selain dianggap praktis dan sangat membantu dalam mendongeng tetapi juga, orang tua sebenarnya khawatir jika anaknya terlalu sering bersama gadget. 
Observasi dilakukan untuk melihat gambaran secara langsung interaksi antara orang tua dan anak, komunikasi serta bagaimana kondisi di lapangan, sehingga didapatkan beberapa poin seperti meskipun sibuk dan sedikit bertemu baik dengan alasan pekerjaan ataupun hal lainnya tetapi saat bersama sample terlihat akrab dan saling menyayangi.hal ini menunjukan adanya kemesraan antara orang tua dan anak yang memang terjalin dengan sendirinya maka dengan semakin seringnya interaksi yang terjadi semakin kuat pula tali kemesraan itu terikat. Observasi terhadap media buku dilakukan untuk mengamati buku dongeng. Pengamatan di lakukan di toko buku Gramedia, Togamas serta pencarian di Internet untuk mengetahui penentuan tampilan visual sebagai referensi. Dari observasi yang dilakukan ditemukan banyaknya buku-buku beredar di pasar untuk anak-anak yang menggunakan ilustrasi sebagai penarik minat si anak. terdapat berbagai ukuran, harga dan warna.

Studi literature digunakan untuk memperkuat pernyataan mengenai hal-hal seputar perancangan buku dongeng ini. seperti mengenai psikologi perkembangan anak, diketahui target adalah anak usia 3,5 tahun-6 tahun yang masuk dalam usia pra sekolah atau bisa disebut sebagai usia tahapan bermain. Dalam tahapan ini seperti yang dituturkan Abu ahmadi (1977) dalam Psikologi perkembangan nak dan remaja (2016). Pada usia pra sekolah anak senang bermain dan terdapat permainan anak yang apresiatif yaitu seperti mendengarkan dongeng,melihat gambar ataupun melihat orang melukis. Dalam permainan ini anak akan mendapat beberapa nilai positif seperti anak dapat mengembangkan daya imajinasi atau kreatifitas.

Dari hasil pengumpulan data yang dilakukan maka didapatkan analisa berupa anakanak usia prasekolah umumnya belum bisa membaca dan mereka lebih banyak menghabiskan waktunya dengan bermain. Meskipun begitu mereka tetap belajar mengenai lingkungan di sekitar mereka. Orang tua memiliki peran penting untuk mengarahkan si anak menuju jalan yang baik salah satunya dengan menanamkan nilai-nilai positif kehidupan itu sendiri. Dongeng merupakan salah satu sarana pembantu untuk menanamkan nilai positif tersebut. Dan dengan segala kendala yang ada orang tua masih memiliki minat yang tinggi dalam mendongeng. Meski kedua orang tua sudah banyak yang keduanya bekerja tetapi tak menyurutkan mereka untuk mendongeng meski dengan intensitas yang tidak terlalu sering. Anak sendiri akan lebih fokus jika dengan gambar karena selain menarik, gambar juga mampu meningkatkan daya imajinasi mereka.

Analisis SWOT adalah sebuah metode analisis yang berbasis analis berupa kekuatan, kelemahan, peluang dan ancaman dari media yang digunakan.

\begin{tabular}{|c|c|}
\hline $\begin{array}{c}\text { Strength (S) } \\
\text { (Kekuatan) }\end{array}$ & $\begin{array}{l}\text { Weakness }(\mathrm{W}) \\
\text { (Kelemahan) }\end{array}$ \\
\hline $\begin{array}{l}\text { - Anak-anak lebih } \\
\text { tertarik dengan } \\
\text { gambar. } \\
\text { - Adanya interaksi } \\
\text { dari pembaca ke } \\
\text { pendengar cerita } \\
\text { begitupun } \\
\text { sebaliknya. } \\
\text { - Ada interaktif } \\
\text { sederhana. } \\
\text { - Mudah dibawa } \\
\text { dan disimpan } \\
\text { dimana mana. } \\
\text { - Lewat buku } \\
\text { yang menarik } \\
\text { secra tidak } \\
\text { langsung dapat } \\
\text { meningkatkan } \\
\text { minat baca pada } \\
\text { anak. }\end{array}$ & $\begin{array}{l}\text { - Anak bahkan } \\
\text { Orang tua banyak } \\
\text { yang tidak } \\
\text { mengetahui cerita } \\
\text { mengenai telaga } \\
\text { warna. } \\
\text { - Buku biasanya } \\
\text { rentan untuk } \\
\text { rusak. } \\
\text { - Pada buku } \\
\text { cerita ini anak } \\
\text { hanya dapat } \\
\text { melihat gambar } \\
\text { karena tidak } \\
\text { bersuara dan } \\
\text { umumunya } \\
\text { belum bisa } \\
\text { membaca } \\
\text { namun orang } \\
\text { tua mampu } \\
\text { untuk } \\
\text { mendongengka } \\
\text { nya kepada } \\
\text { anak. }\end{array}$ \\
\hline $\begin{array}{l}\text { Opportunity (O) } \\
\text { (Peluang) }\end{array}$ & $\begin{array}{l}\text { Threats }(\mathrm{T}) \\
\text { (Ancaman) }\end{array}$ \\
\hline
\end{tabular}


- Mendongeng masih dilakukan meskipun tidak sering dilakukan.

- Anak-anak senang melakukan hal yang menarik baginya.

- Dianggap lebih aman daripada gadget

- Anak memiliki rasa ingin tahu yang tinggi.

- Menjadi salah satu alternatif media yang mengasyikan selain gadget.
- Perkembangan teknologi yang memancing anak untuk lebih sering bersama gadget.

- Pada umumnya anak usia pra sekolah belum dapat membaca.

\section{Referensi Karakter}

Karakter adalah watak, sifat, ciri khas individu yang mempengaruhi segala tabiat, perilaku dan budi pekerti yang dimiliki manusia atau makhluk hidup lainnya, berikut referensi karakter yang dipakai dalam perancangan berupa tokoh, atribut, penggambaran dan lain-lain.
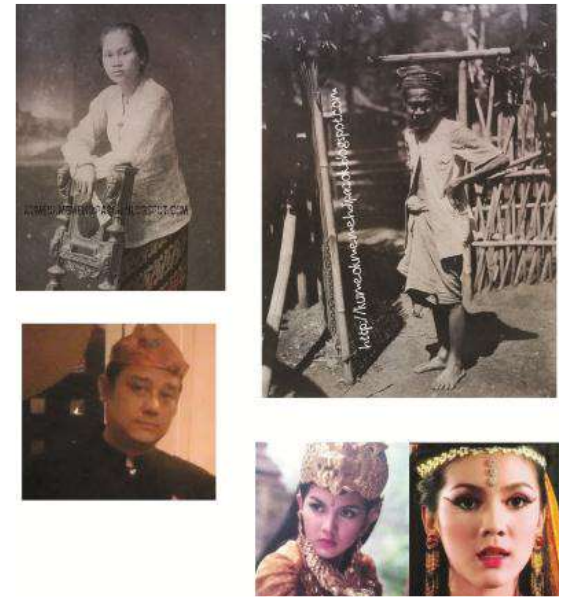
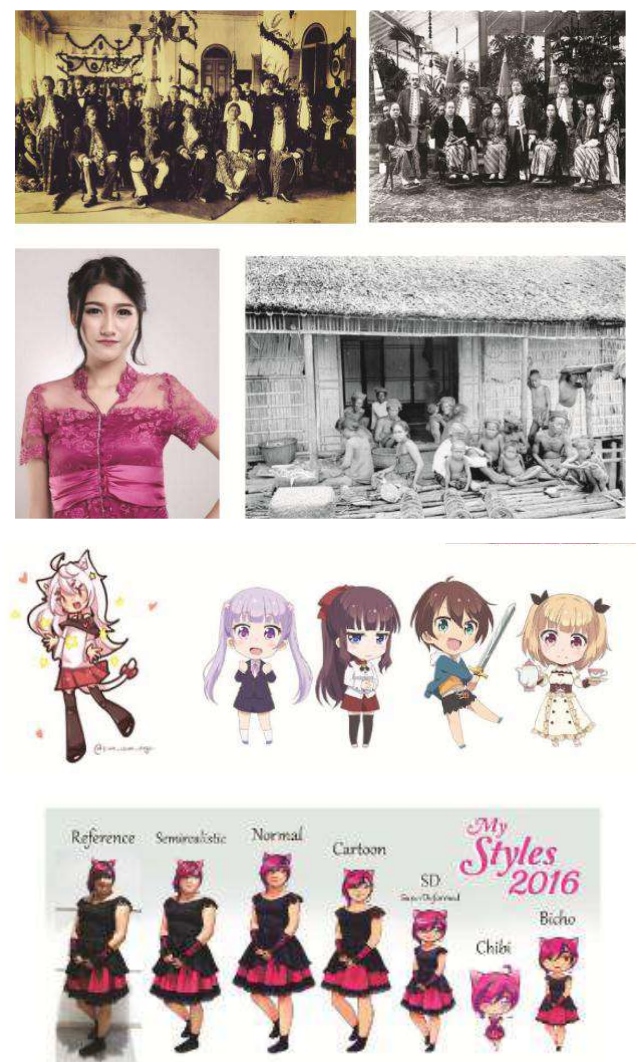

Referensi karakter

Sumber Penelitian Pribadi (2018)

\section{Referensi Visual}

Referensi Visual merupakan acuan atau pedoman dalam hal visual, atau penampakkan semua hal yang terlihat dalam media yang visualnya akan dipakai dalam perancangan. Dari data yang ada didapatkan beberapa visual yang dapat dijadikan refrensi sebagai berikut:

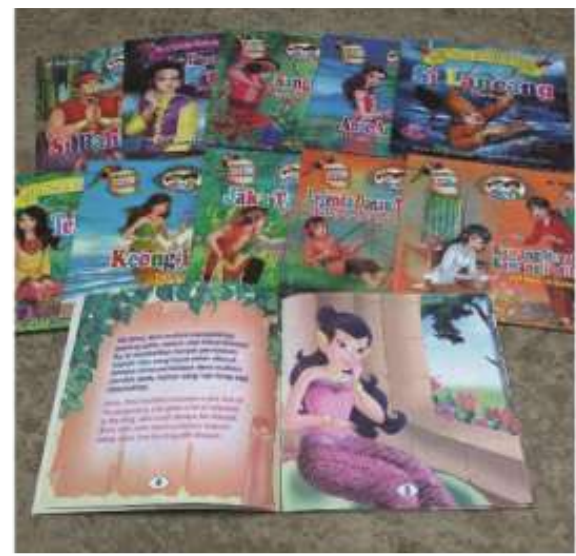




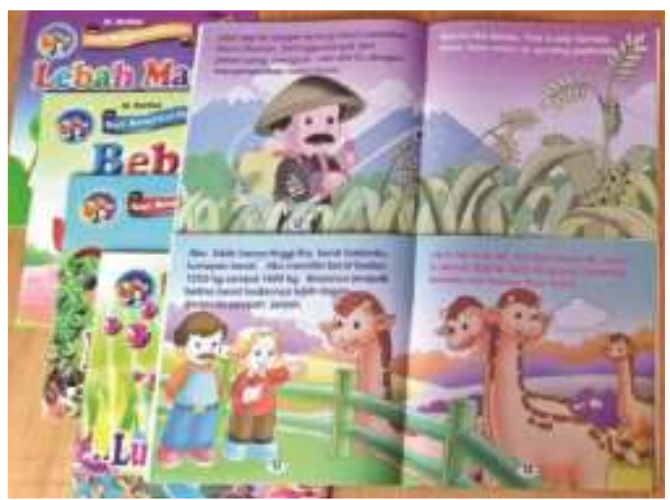

Referensi Visual

Sumber Penelitian Pribadi (2018)

\section{Referensi Desain}

Referensi Desain merupakan pedoman dalam hal desain, dalam hal ini desain berupa media buku cerita anak. Dari data yang ada didapat beberapa referensi desain sebagai berikut:
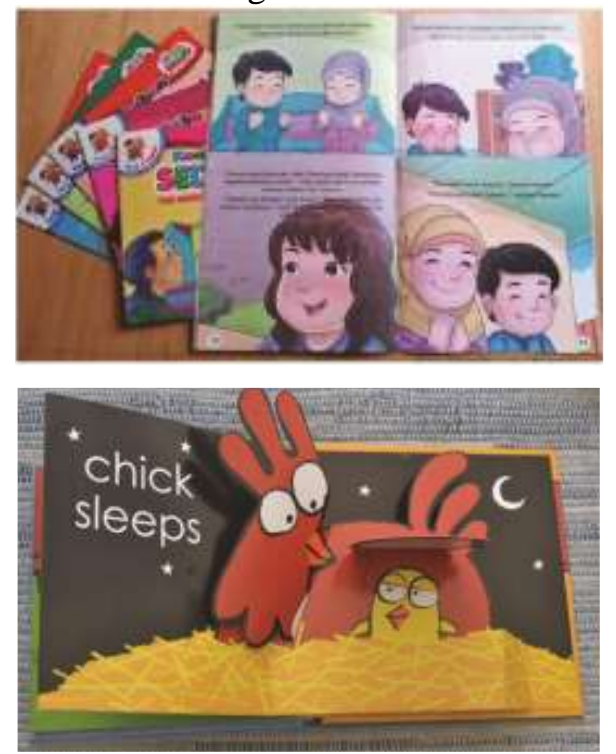

\section{Referensi Desain}

Sumber Penelitian Pribadi (2018)

\section{Referensi Media Buku}

Referensi Media Buku adalah suatu pedoman ataupun dasar dalam merancang suatu media berupa buku. Dari data yang ada didapat beberapa referensi media buku sebagai berikut:

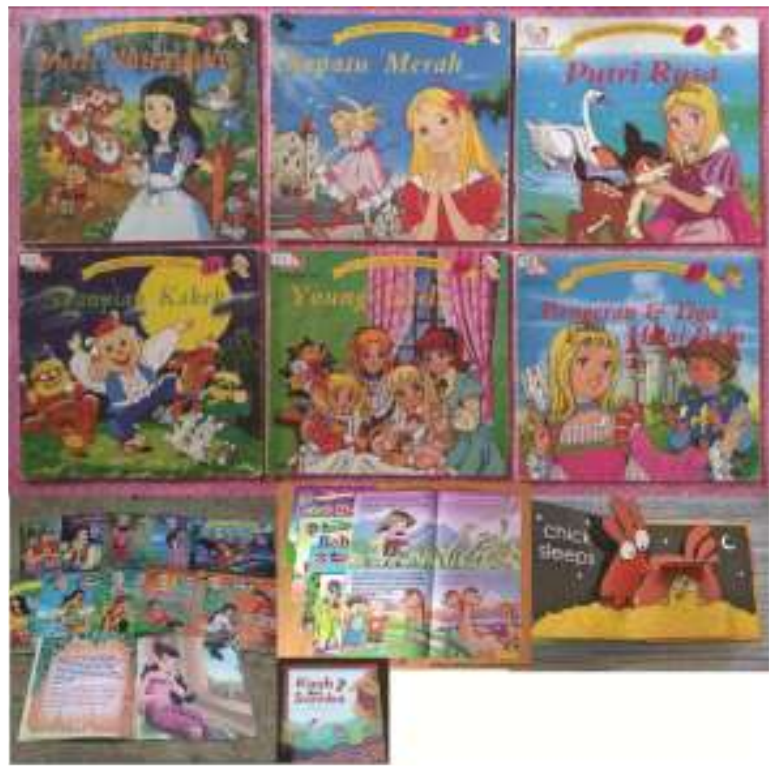

Referensi Media Buku

Sumber Penelitian Pribadi (2018)

Berdasarkan wawancara yang dilakukan terhadap beberapa responden, maka didapatkan insight bahwa target yang umumnya pada usia pra sekolah banyak menghabiskan waktunya dengan bermain baik itu bermain di dalam ruangan seperti bermain gadget, melihat-lihat buku ataupun di luar atau permainan yang melatih motorik kasar seperti sepak bola, badminton dan lainnya. Anak anak memiliki rasa ingin tahu yang tinggi, senang bermain dan menyukai halhal baru. Dalam kegiatan mendongeng biasanya anak akan lebih fokus saat bercerita atau mendongeng dengan memperlihatkan gambar, biasanya berupa buku karena dianggap orang tua lebih praktis dan dapat membantu mereka dalam mendongeng sekaligus dapat menjauhkan sementara anak dari gadget.

Informasi yang akan diberikan kepada target akan dikemas dalam media berupa buku dongeng Interaktif. Media ini akan berisi tentang dongeng telaga warna yaitu sebuah dongeng dari jawa barat yang menceritakan mengenai seorang putri yang sembong serta orang-orang yang menyayanginya. Dengan beberapa interaksi sederhana di dalam buku dongeng interaktif tersebut.

Isi pesan yang ingin disampaikan kepada target audience adalah untuk memberikan alternatif cerita yang mengandung nilai-nilai positif kehidupan sekaligus yang dalam cerita telaga warna ini berupa pesan tidak boleh sombong dan jangan menyakiti orang-orang di sekitar kita. Serta pesan tersirat bagi orang tua yaitu jangan terlalu memanjakan anak-anaknya 
karena justru akan berdampak buruk bagi si anak.

Untuk menyampaikan pesan tersebut, Informasi yang akan diberikan kepada target akan dikemas dalam media berupa buku dongeng Interaktif. Media ini akan berisi tentang dongeng telaga warna yaitu sebuah dongeng dari jawa barat yang disajikan dengan full gambar ilustrasi untuk memenuhi kebutuhan anak prasekolah dapat mengikuti cerita dalam buku dongeng tersebut. Dalam buku ini pun diberikan beberapa interaksi sederhana di dalam buku dongeng interaktif tersebut.

\section{HASIL DAN PEMBAHASAN}

Perancangan media berupa buku dongeng interaktif mempunyai dimensi buku $20 \times 20 \mathrm{~cm}$ yang bertujuan agar mudah dibaca dan dilihat terutama untuk target yang masih dalam usia prasekolah. Dalam perancangan buku interaktif dongeng telaga warna, yang pertama kali di lakukan ialah menyadur cerita dongeng tentang telaga warna ini dibuat sebuah rangkaiyan cerita yang sederhana dan dapat diikuti alurnya oleh anak-anak usia prasekolah, cerita tersebut dapat berasal dari beberapa sumber. Kemudian dibuatlah sebuah alur cerita tersebut berupa storyline.

\section{Storyline (alur cerita)}

\begin{tabular}{|c|l|}
\hline No. & \multicolumn{1}{|c|}{ Scene (Adegan) } \\
\hline Scene 1 & $\begin{array}{l}\text { Jaman dahulu ada sebuah kerajaan } \\
\text { di Jawa Barat bernama } \\
\text { Kutatanggeuhan. Kutatanggeuhan } \\
\text { merupakan kerajaan yang } \\
\text { makmur dan damai }\end{array}$ \\
\hline Scene 2 & $\begin{array}{l}\text { Prabu Suwartalaya dan } \\
\text { permaisurinya bernama Ratu } \\
\text { Purbamanah belum dikaruniai } \\
\text { keturunan sehingga mereka selalu } \\
\text { merasa kesepian. }\end{array}$ \\
\hline
\end{tabular}

\begin{tabular}{|c|c|}
\hline Scene 3 & $\begin{array}{l}\text { Akhirnya Raja memutuskan untuk } \\
\text { bersemedi. Dia pergi dan } \\
\text { menemukan sebuah gua. } \\
\text { Disanalah dia bersemedi, berdoa } \\
\text { kepada Tuhan supaya dikaruniai } \\
\text { keturunan. }\end{array}$ \\
\hline Scene 4 & $\begin{array}{l}\text { suatu hari tiba-tiba terdengar } \\
\text { suara gaib yang menjamin dia } \\
\text { akan segera memiliki keturunan. }\end{array}$ \\
\hline Scene 5 & $\begin{array}{l}\text { beberapa minggu kemudian, Ratu } \\
\text { pun mengandung.lalu sembilan } \\
\text { bulan kemudian Ratu melahirkan } \\
\text { seorang putri yang cantik. Dia } \\
\text { diberi nama Putri Gilang } \\
\text { Rukmini. }\end{array}$ \\
\hline Scene 6 & $\begin{array}{l}\text { putri Gilang Rukmini tumbuh } \\
\text { menjadi gadis yang cantik jelita. } \\
\text { Sayang putri Gilang Rukmini } \\
\text { sangat manja dan berperangai } \\
\text { tidak baik. }\end{array}$ \\
\hline Scene 7 & $\begin{array}{l}\text { putri Gilang Rukmini akan } \\
\text { berusia tujuh belas tahun. Rakyat } \\
\text { berkumpul dan merencanakan } \\
\text { hadiah istimewa untuk putri } \\
\text { kesayangan mereka. Akhirnya } \\
\text { disepakati bahwa mereka akan } \\
\text { menghadiahkan sebuah kalung } \\
\text { yang sangat indah. }\end{array}$ \\
\hline Scene 8 & $\begin{array}{l}\text { rakyat dengan sukarela } \\
\text { menyisihkan uang mereka dan } \\
\text { mengumpulkannya untuk biaya } \\
\text { pembuatan hadiah tersebut. } \\
\text { Mereka memanggil pandai emas }\end{array}$ \\
\hline
\end{tabular}




\begin{tabular}{|l|l|}
\hline & $\begin{array}{l}\text { terbaik di kerajaan untuk } \\
\text { membuatnya. }\end{array}$ \\
\hline Scene 9 & $\begin{array}{l}\text { Rakyat berduyun-duyun datang ke } \\
\text { halaman istana tempat pesta ulang } \\
\text { tahun putri Gilang Rukmini } \\
\text { diadakan. Di depan istana }\end{array}$ \\
\hline
\end{tabular}

\section{Ilustrasi Karakter dan Studi Visual}

Dalam pembuatan ilustrasi untuk buku dongeng Talaga Warna, dimulai dengan merancang karakter berdasarkan tokoh yang muncul dalam dongeng Talaga Warna. Studi karakter ini berdasarkan eksperimen yang mengacu pada beberapa referensi visual, serta melihat kesesuaian antara gaya ilustrasi deformasi yang dibuat, kemudian penambahan unsur dari referensi-referensi yang ada sebagai dasar ilustrasi buku, hal ini juga menyesuaikan dengan cerita dan target pembacanya.

Dalam dongeng Talaga Warna ini muncul beberapa nama tokoh yang menjadi tokoh utama dalam dongeng ini, diantaranya adalah Putri Gilang Rukmini, Prabu Suwartalaya dan Ratu Purbamanah. Berikut adalah karakter yang tercipta untuk mewakili ketiga tokoh utama dalam dongeng Talaga Warna.

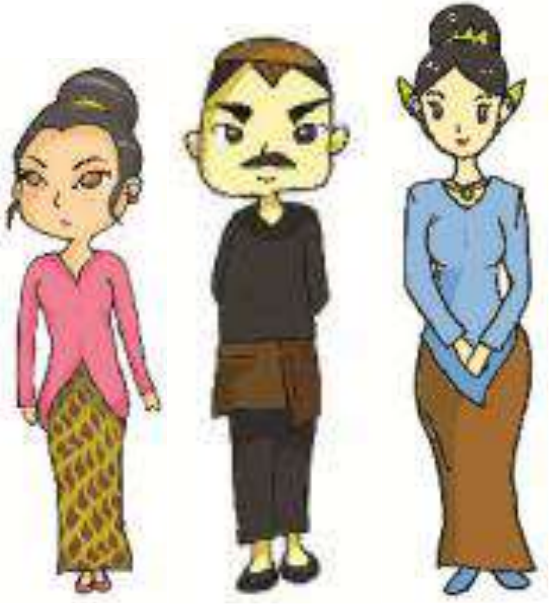

karakter tokoh utama Sumber : Karya Pribadi
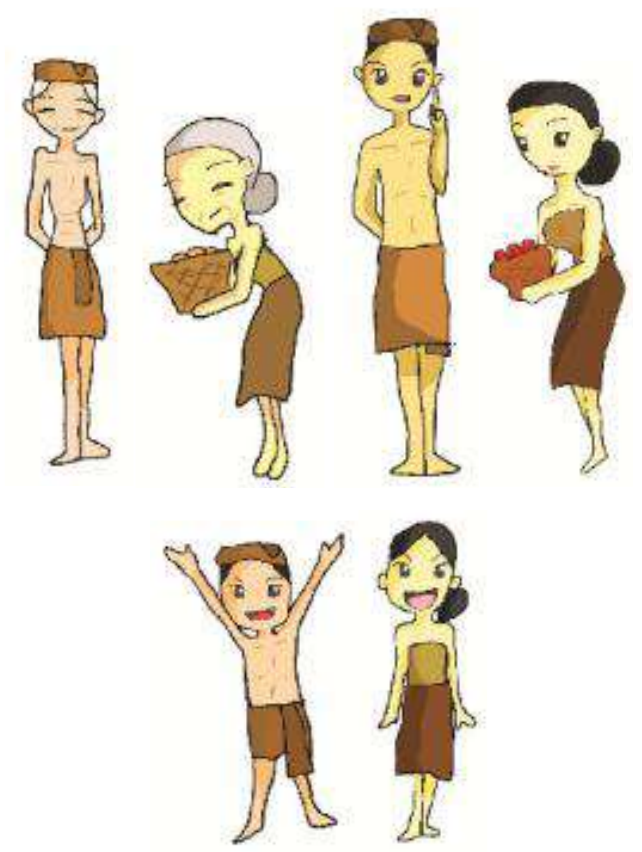

karakter figuran (rakyat)

Sumber: Karya Pribadi
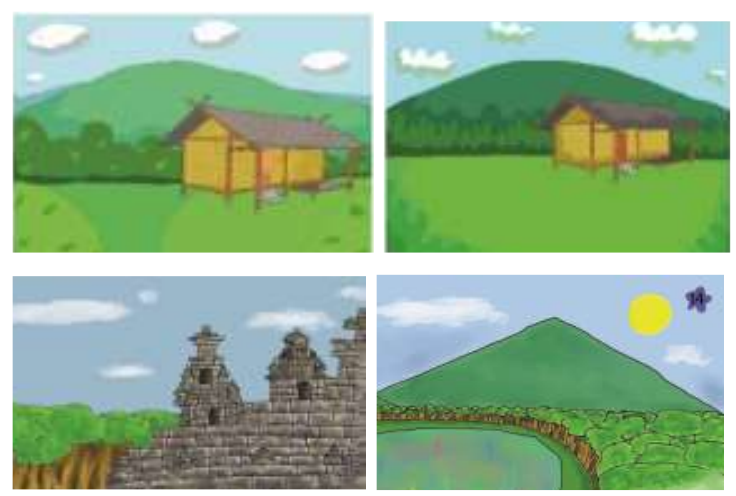

Alternatif Latar tempat

Sumber: Karya Pribadi

Selain karakter tokoh utama dalam dongeng, juga dibuat beberapa karakter yang bertujuan mewakili rakyat atau penduduk desa. Disamping studi karakter, dibuat juga beberapa studi yang berkenaan dengan latar atau background.

\section{Grid System}

Grid system ataupun sistem grid pada layout isi adalah pedoman ataupun acuan berupa garis horizontal dan vertikal yang membentuk kolom dan baris tertentu dengan tujuan agar layout nantinya memiliki satu sistem yang sama 


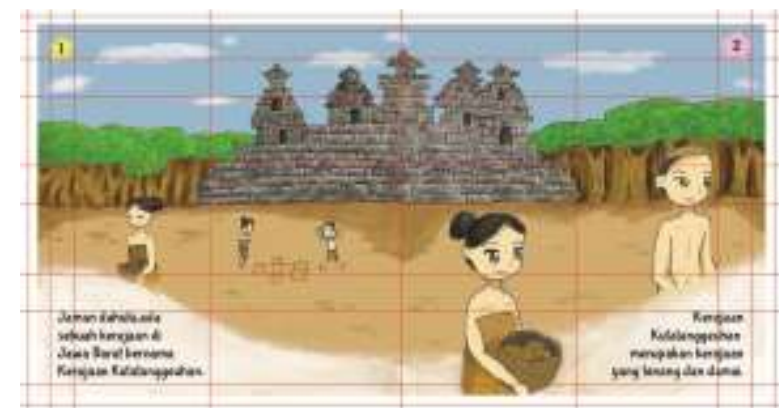

Grid system

Sumber : Karya Pribadi

Grid pada layout isi buku ini berupa bagian bodycopy yang merupakan alur cerita berupa tipografi serta gambar ilustrasi dengan layout yang sama berupa bagian berwarna putih dan juga dengan penomoran halaman di bagian atas halaman.

\section{Perancangan Isi Buku}

Isi Buku terdiri dari 14 halaman dan dpenuh dengan gambar ilustrasi cerita tersebut dalam setiap halaman ada satu unsur interaktif pada halaman tersebut seperti flip, slide dan tarik. Berikut adalah bagian isi buku yang terdapat pada buku dongeng Talaga Warna.

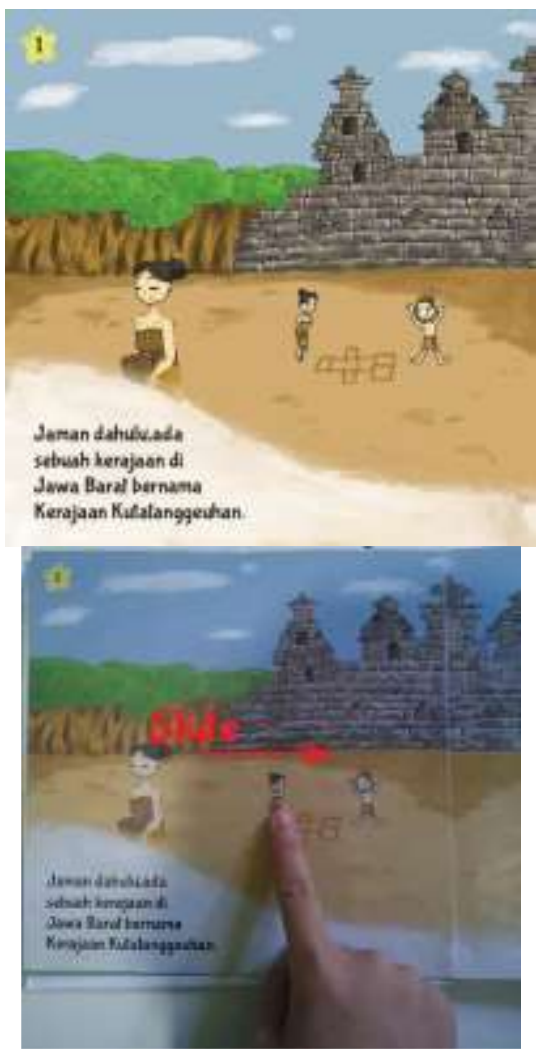

Cerita : Dahulu, ada kerajaan di Jawa barat bernama Kerajaan Kutatanggeuhan, kerajaan kutatanggeuhan merupakan kerajaan yang damai. Aspek Perkembangan:

- Mengenal Susana kerajaan jaman dahulu.

- (Motorik halus) pada Interaktif gadis kecil bermain engklek

Keterangan: slide
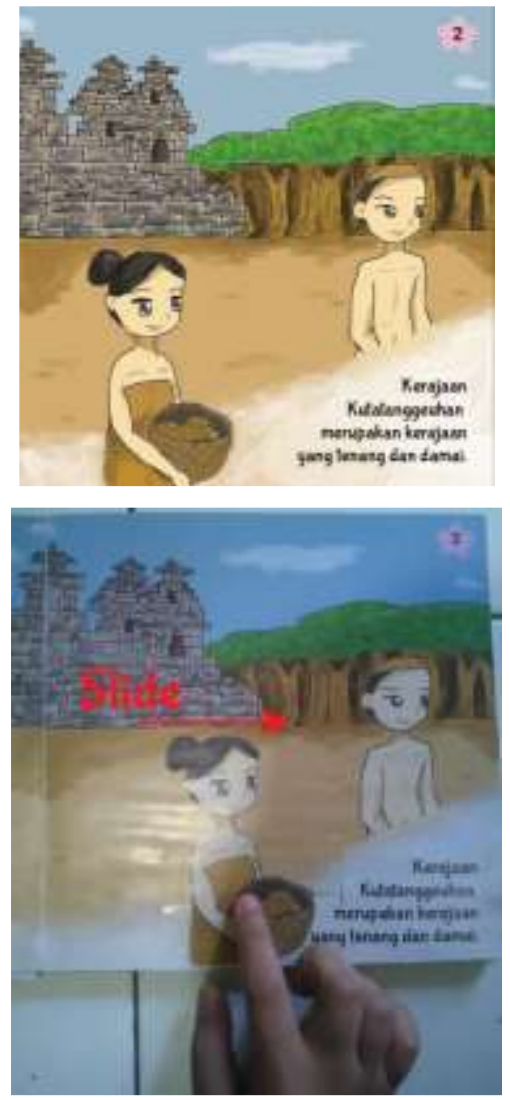

Cerita : Dahulu, ada kerajaan di Jawa barat bernama Kerajaan Kutatanggeuhan, kerajaan kutatanggeuhan merupakan kerajaan yang damai. Aspek Perkembangan:

- Mengenal Susana kerajaan jaman dahulu.

- (Motorik halus) pada Interaktif dan gadis yang membawa keranjang di halaman 2 .

Keterangan: slide 

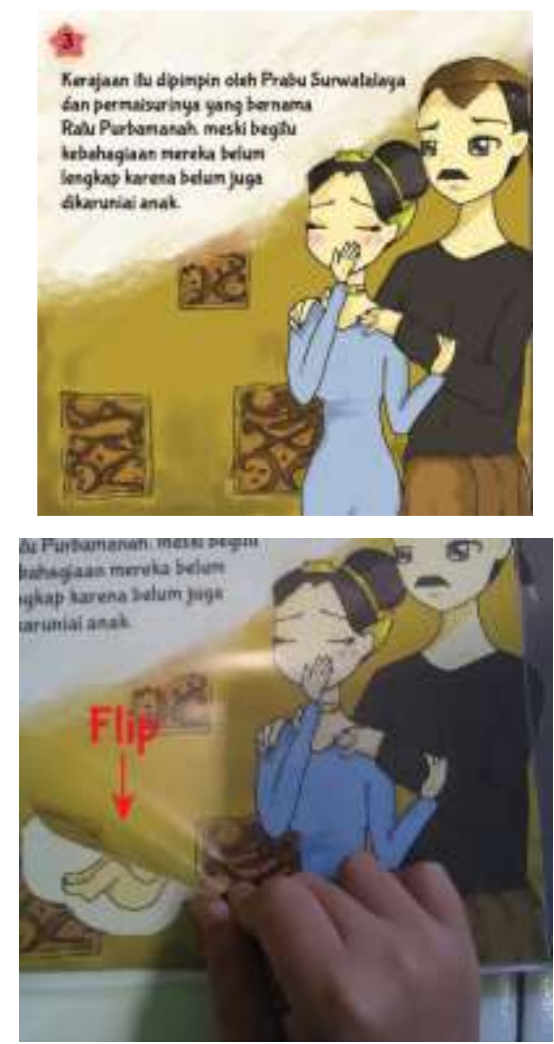

Cerita : Namun Raja dan ratu bersedih karena belum juga dikaruniai anak.

Aspek Perkembangan:

- Mengenal perbedaan pakaian Raja dan ratu.

- Rasa Sedih (pada saat raja dan ratu bersedih) Keterangan: Flip

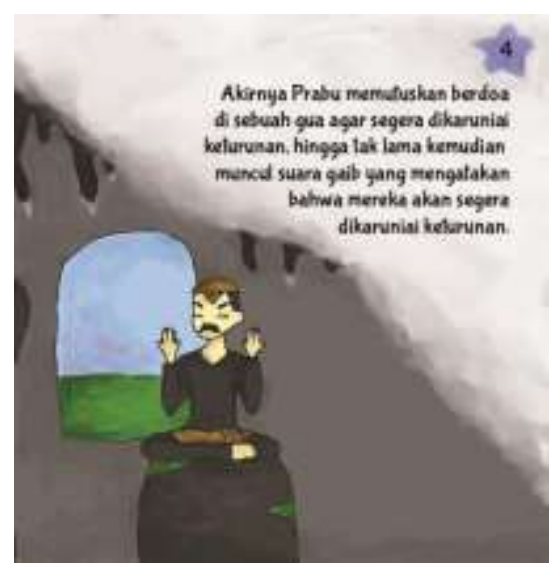

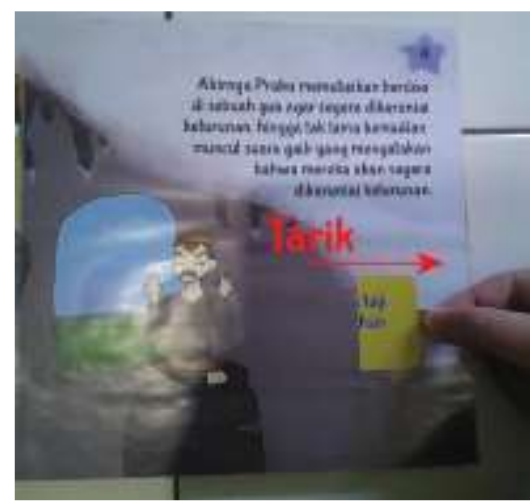

Cerita: Raja memutuskan untuk berdoa di sebuah gua hingga akhirnya muncul pertanda bahwa mereka akan segera dikaruniai keturunan.

Aspek Perkembangan:

- Berusaha keras dan Berdoa (saat Raja berdoa untuk dikaruniai anak).

Keterangan: Ditarik
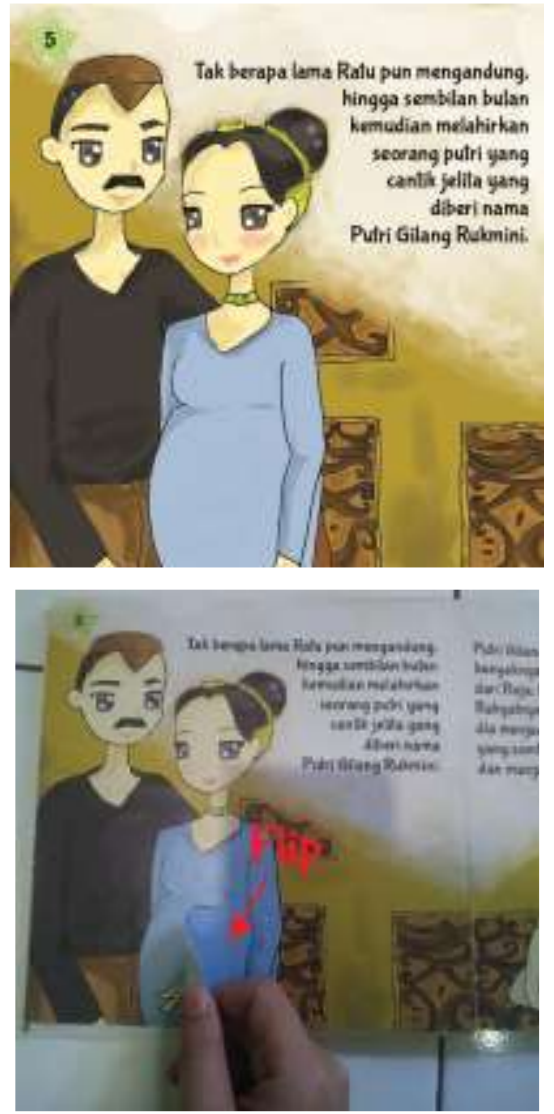

Cerita : Tak lama kemudian ratu mengandung dan melahirkan seorang putri yang cantik.

Aspek Perkembangan:

- Merasakan suasana kerajaan tradisional

- Kesabaran berbuah hasil (saat Raja dan ratu yang akhirnya mempunyai anak)

Keterangan: Flip 

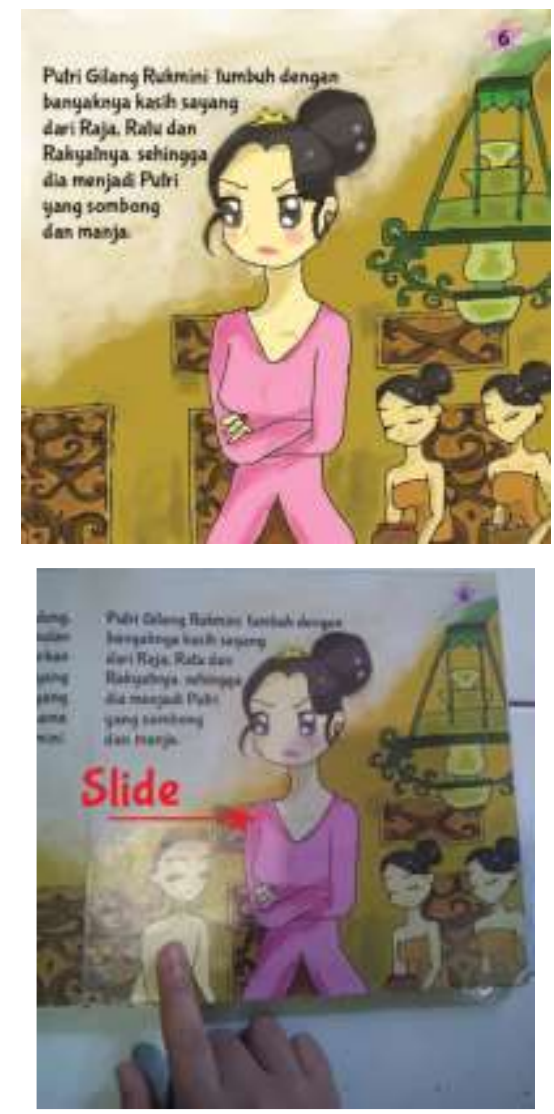

Cerita; Namun putri tersebut tumbuh menjadi pribadi yang sombong dan manja.

Aspek Perkembangan:

- Sifat buruk (putri yang sombong dan manja) Keterangan: Slide

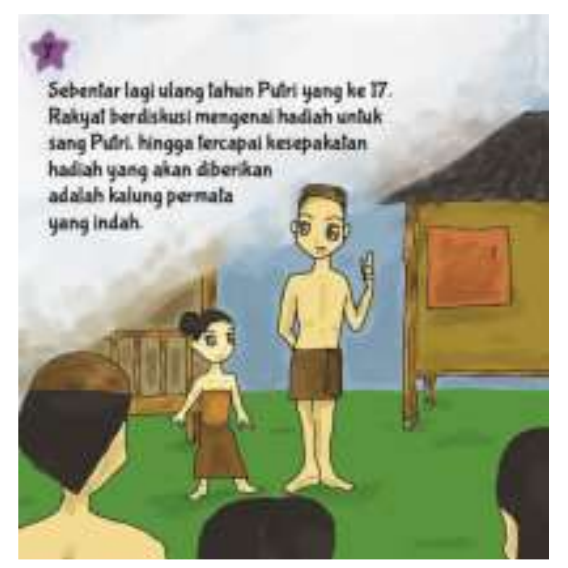

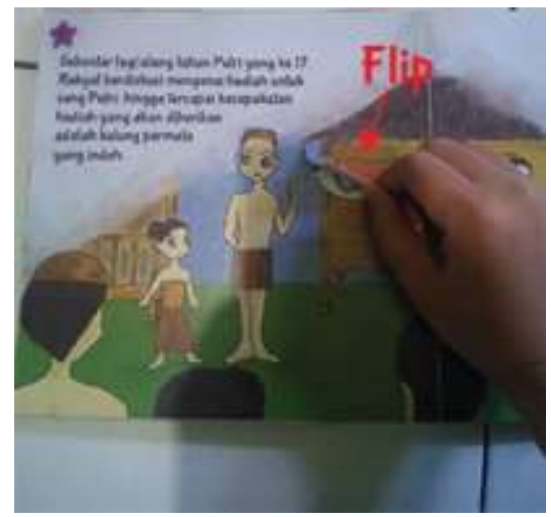

Cerita : Hari ulang tahun putri yang ke 17 akan berlangsung, rakyat pun berdiskusi mengenai hadiah yang akan diberikan kepada putri Aspek Perkembangan:

- Mengenal suasana rakyat di jaman kerajaan dulu.

- Musyawarah (saat rakyat berdiskusi) Keterangan: Flip

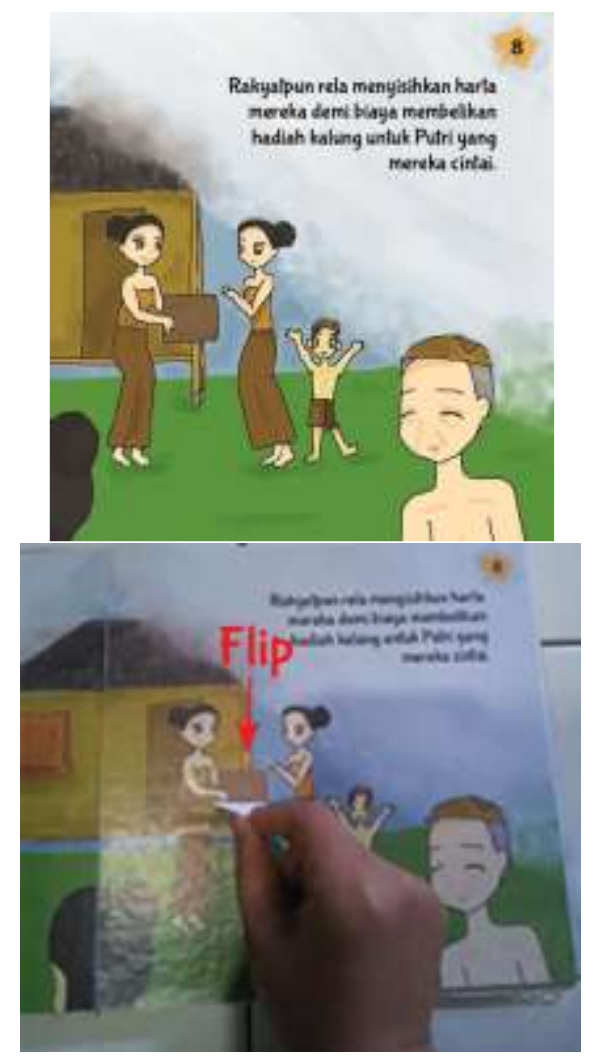

Cerita: Rakyat lalu menyisihkan harta mereka untuk membeli hadiah tersebut.

Aspek Perkembangan:

- Bekerja sama (saat rakyat patungan untuk membelikan hadiah putri)

Keterangan: Flip 

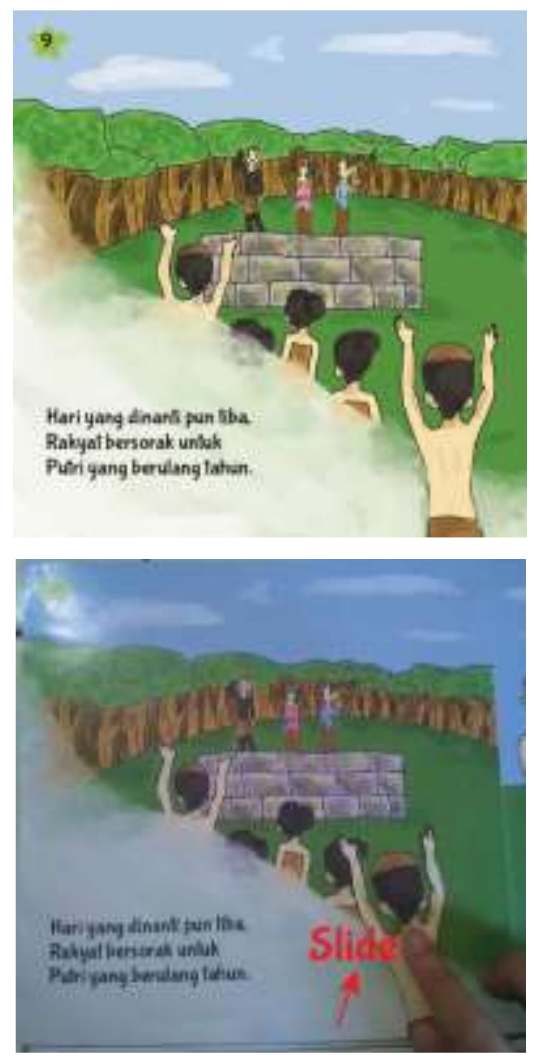

Cerita : Hari ulang tahun pun tiba.

Aspek Perkembangan:

- Rasa Senang (saat Raja,Ratu dan Rakyat bahagia dengan ulang tahun putri)

Keterangan: Slide

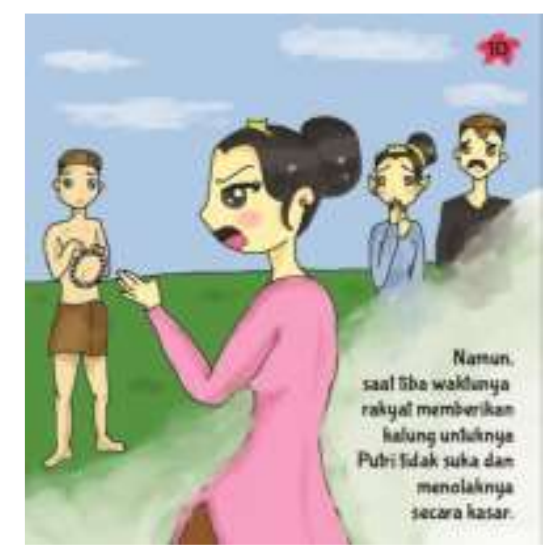

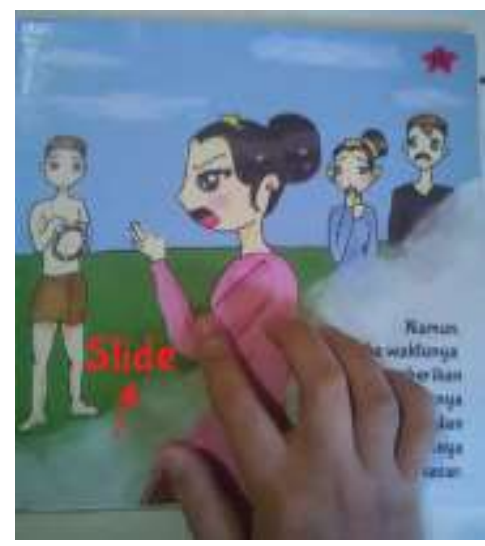

Cerita: namun saat rakyat akan memberikannya hadiah kalung tersebut Putri menolaknya secara kasar.

Aspek Perkembangan:

- Sikap Buruk (Putri menolak pemberian dengan kasar)

- Rasa sedih (perasaan semua orang atas tingkah sang putri).

Keterangan: Slide

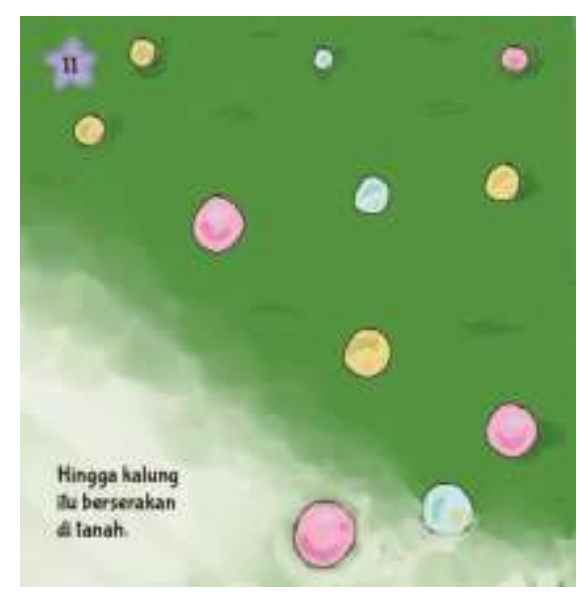

Cerita : Kalungpun berserakan di tanah

Keterangan: -

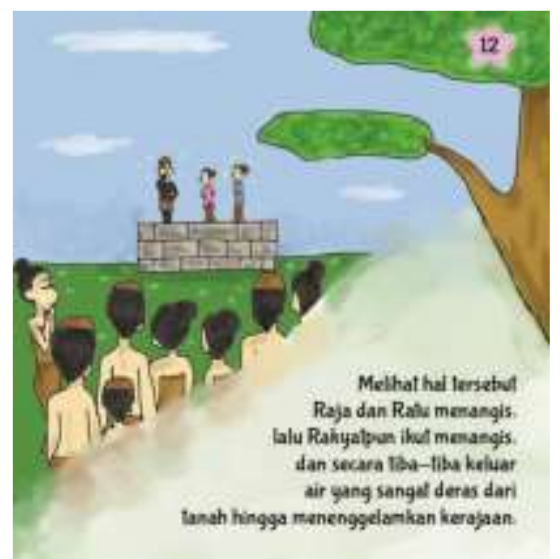




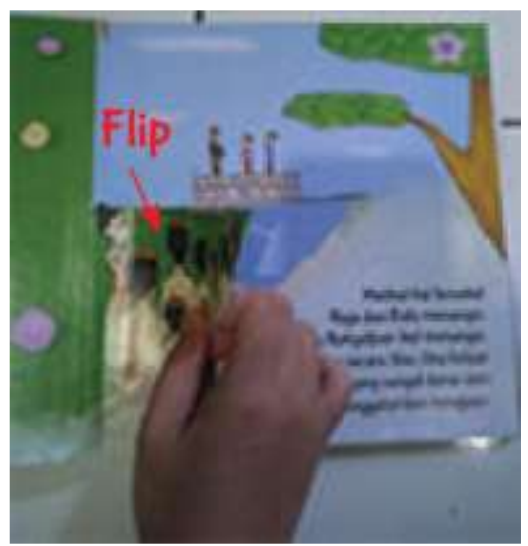

Cerita: Raja, dan ratu mulai menangis diikuti Rakyat yang juga menangis atas perlakuan sang putri. Hingga keluarlah air yang deras sampai menenggelamkan kerajaan.

Aspek Perkembangan:

- Rasa sedih bercampur kecewa (atas perlakuan si putri)

Keterangan: Flip
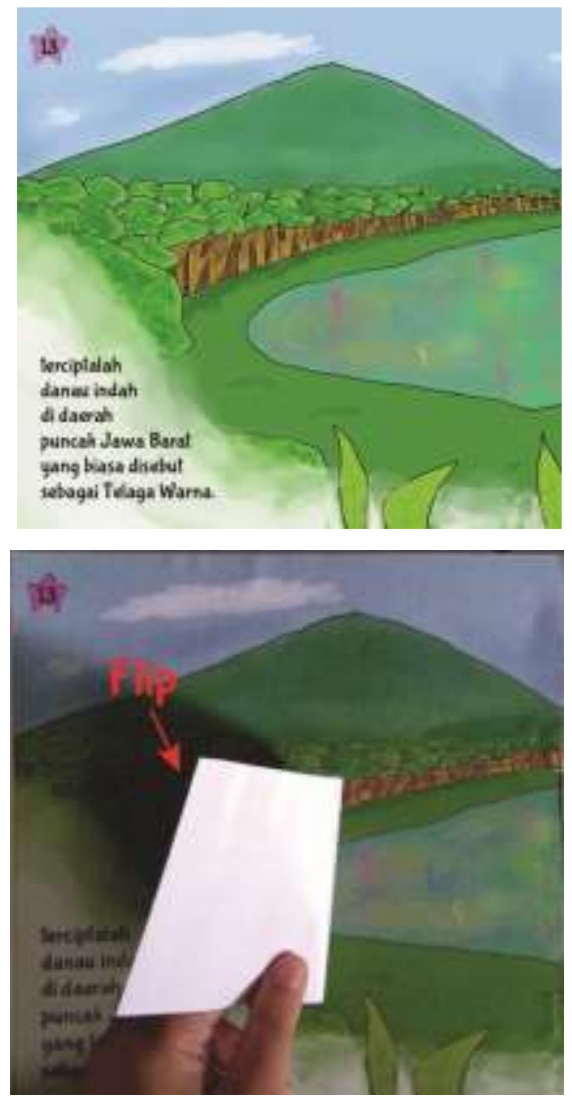

Cerita : Terciptalah telaga warna, konon jika hari cerah telaga akan berubah warna dan kelap kelip warna tersebut katanya berasal dari kalung putri. Aspek Perkembangan:
- Mengenal telaga warna

Keterangan: Flip
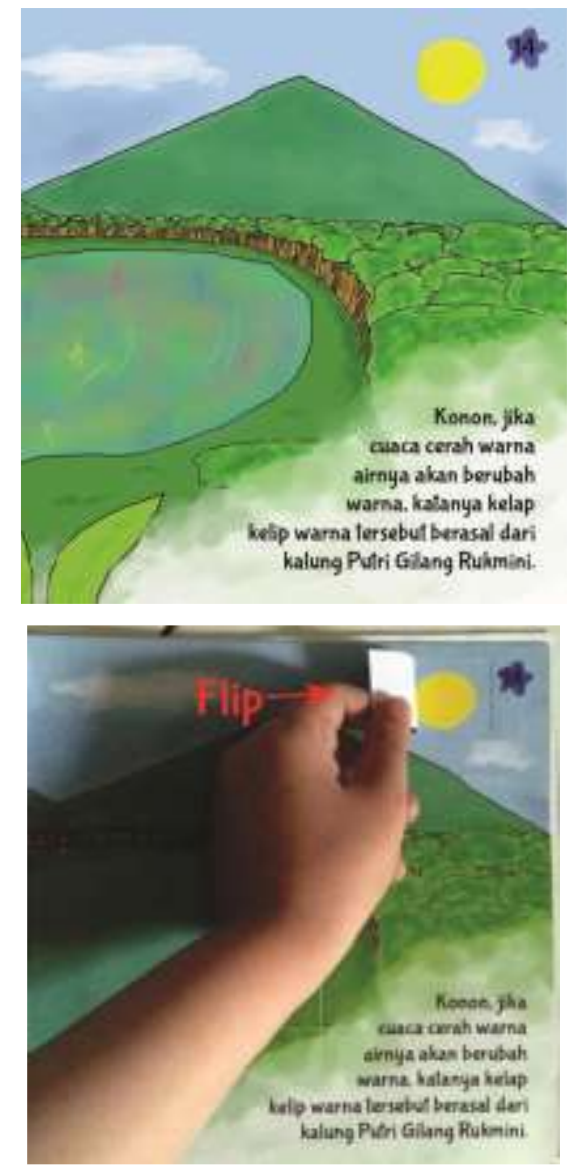

Cerita : Terciptalah telaga warna, konon jika hari cerah telaga akan berubah warna dan kelap kelip warna tersebut katanya berasal dari kalung putri.

Aspek Perkembangan:

- Mengenal telaga warna

Keterangan: Flip

\section{Sampul Buku}

Dalam perancangan sampul depan dan sampul belakang pada buku deongeng ini menggunakan gambar ilustrasi, ilustrasi yang diterapkan pada sampul depan dari buku ini terpusat pada tokoh Putri Gilang Rukmini sebagai tokoh utama, serta kunci kejadian dalam peristiwa terbentuknya Telaga Warna, pada sampul belakang, menerapkan ilustrasi yang sama seperti gambar dalam latar pada halaman depan. 

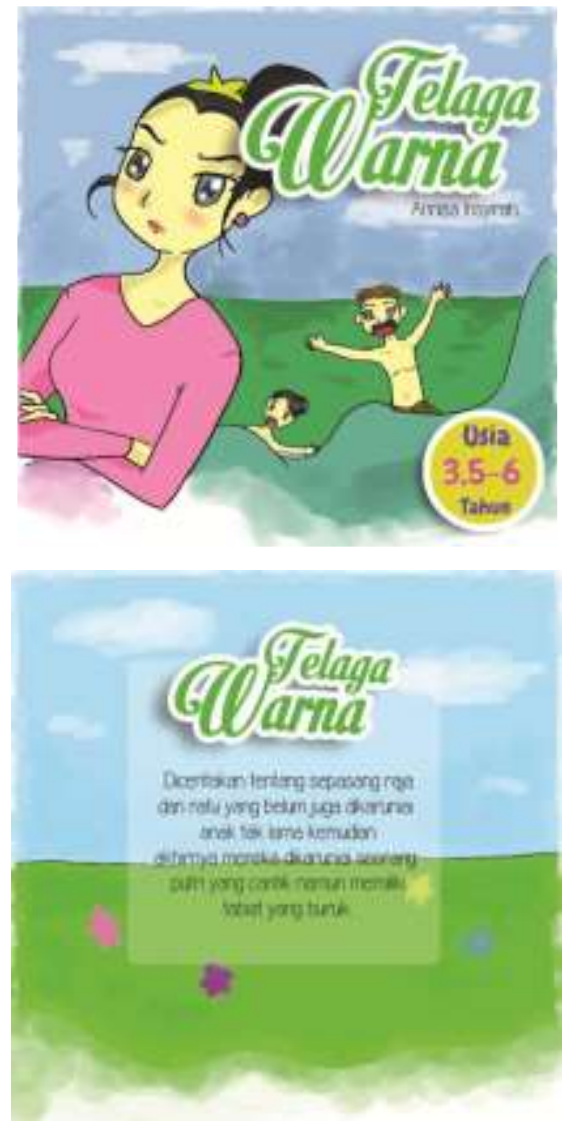

Sampul depan dan sampul belakang

Sumber : Karya Pribadi

\section{KESIMPULAN}

Berdasarkan hasil penelitian serta analisis dan perancangan yang dilakukan, maka dapat ditarik kesimpulan sebagai berikut:

Dongeng dapat dijadikan metode alternatif untuk menanamkan pembelajaran moral dan nilai-nilai positif kehidupan karena di dalamnya tersirat pesan yang biasanya berupa perbuatan baik dan buruk. Guna memfasilitasi orang tua dalam mendongeng kepada anaknya yang masih usia prasekolah, maka buku dongeng interaktif dapat menjadi solusinya, penggunaan gambar ilustrasi dalam buku ini juga selain berfungsi sebagai penghias buku dongeng yang untuk anak-anak juga berfungsi sebagai pengantar cerita bagi anak yang belum dapat membaca.

Ilustrasi yang menarik dapat membantu menyampaikan pesan atau cerita yang ada didalamnya. Ilustrasi dengan pendekatan semi realis diharapkan membantu memperjelas dan menggambarkan cerita talaga warna sehingga mudah dipahami oleh anak-anak san orang tua sebagai sarana mendongeng.
Adanya unsur interaktif sederhana dalam buku dongeng telaga warna ini juga dapat menambah keseruan saat membaca dongeng telaga warna ini.

Saran dari peneliti terkait "Perancangan Ilustrasi Buku Dongeng Telaga Warna" dapat dilengkapi lagi terutama berkenaan dengan perancangan ilustrasi yang tepat dan menarik untuk disajikan dalam buku dongeng. Serta merancang bentuk interaksi yang lebih atraktif dan menarik. Peneliti juga menyarankan media ini dapat teraplikasikan juga untuk dongeng nusantara yang lainnya.

\section{REFERENSI}

Kusrianto Adi (2009) Pengantar Desain Komunikasi Visual. Yogyakarta. Penerbit Andi

Prof.Dr.H.Yusuf Syamsu I.N,M.Pd (2016) Psikologi Perkembangan Anak dan Remaja. Bandung. PT Remaja Rosdakarya Offset

Suherman Bonnie, Wirawan R Adhicipta Ele (2009) Mastering Chibi Karakter. Jakarta. PT x Media Komputindo

Sugihastuti (2013) Tentang cerita anak.Yogyakarta.Pustaka Pelajar

\section{Website}

http://1001buku.org/author/riset-dan-

pengembangan/ (diakses pada tanggal 21 November 2018)

https://dokumen.tips/documents/pembelajaranapresiasi-sastra-di-sd.html (diakses pada tanggal 13 Desember 2018)

https://edukasi.kompas.com/read/2012/05/21/161 11394/usia.berapa.anak.boleh.diberi.donge ng (diakses pada tanggal 15 November 2018)

https://www.suara.com/lifestyle/2016/08/07/170 000/ini-manfaat-mendongeng-bagi-anakdan-orangtua (diakses pada tanggal 15 November 2018) 